\title{
Pengaruh ekstrak melon terhadap kadar HbCO pada tikus Wistar jantan yang dipapar asap rokok
}

Melon extract effect for HbCO level on male Wistar rats exposed of cigarette smoke

\author{
Yuyun Erlina Susanti ${ }^{1}$, Bambang Wirjatmadi ${ }^{2}$, Merryana Adriani ${ }^{2}$
}

${ }^{1}$ Fakultas Kesehatan Masyarakat, Universitas Airlangga

${ }^{2}$ Departemen Gizi Masyarakat, Fakultas Kesehatan Masyarakat, Universitas Airlangga

\begin{abstract}
Background: Smoking is something that is usual for most Indonesian society, especially adult males. According to Riskedas, smoking behavior of the population trends to increase. A previous study suggested that exposure to cigarette smoke produce CO bond to hemoglobin. Melon (Cucumis melo) contains antioxidants that prevent tissue damage. Objective: Analyze differences in levels $\mathrm{HbCO}$ Wistar male rats in treated and untreated extracts of melon. Method: The research was a laboratory experiment with the post test control group design and complete random design. The subjects were 25 male Wistar rats aged 3 months. Subjects were divided into 5 groups and each group received treatment for 28 days. Data of level $\mathrm{HbCO}$ was collected and analyzed by Anova One Way test at 95\% confidence level. Results: The results showed a difference between the average levels of HbCO male Wistar rats ( $p$ value $=0,000)$ treated and untreated extracts of melon. Conclusion: Melon extracts effect on decreasing the levels of $\mathrm{HbCO}$ due to exposure to cigarette smoke. There were differences in levels of male Wistar rats HbCO on treated and untreated extracts of melon and be given at a dose of 250 IU/day.
\end{abstract}

KEY WORDS: smoke; melon extract; $\mathrm{HbCO}$

\begin{abstract}
ABSTRAK
Latar belakang: Merokok merupakan sesuatu hal yang biasa bagi kebanyakan masyarakat Indonesia terutama lelaki dewasa. Menurut Riskedas, perilaku merokok penduduk cenderung meningkat. Pada beberapa penelitian, paparan asap rokok menghasilkan ikatan CO terhadap hemoglobin (Hb). Melon (Cucumis melo) mengandung antioksidan yang mencegah kerusakan jaringan. Tujuan: Menganalisis perbedaan kadar $\mathrm{HbCO}$ pada tikus Wistar jantan yang diberi perlakuan dan tidak diberi perlakuan ekstrak melon. Metode: Jenis penelitian ini adalah eksperimen laboratoris dengan menggunakan control group post test design dengan menggunakan metode rancangan acak lengkap (RAL). Sampel dalam penelitian ini sebanyak 25 ekor tikus Wistar jantan usia 3 bulan. Subjek dibagi 5 kelompok yang masing-masing mendapat perlakuan selama 28 hari. Data kadar HbCO dikumpulkan dan dianalisis dengan uji Anova One Way pada tingkat kepercayaan 95\%. Hasil: Hasil penelitian menunjukkan ada perbedaan rerata kadar $\operatorname{HbCO}(p=0,000)$ pada tikus Wistar jantan yang diberi perlakuan dan tidak diberi perlakuan ekstrak melon. Simpulan: Ekstrak melon berpengaruh terhadap penurunan kadar $\mathrm{HbCO}$ akibat paparan asap rokok. Terdapat perbedaan kadar $\mathrm{HBCO}$ pada tikus Wistar jantan yang diberi perlakuan dan tidak diberi perlakuan ekstrak melon pada pemberian dosis $250 \mathrm{IU} / \mathrm{hari}$.
\end{abstract}

KATA KUNCI: asap rokok; ekstrak melon; $\mathrm{HbCO}$

\section{PENDAHULUAN}

Merokok merupakan sesuatu hal yang biasa bagi kebanyakan mayarakat Indonesia terutama lelaki dewasa (1). Menurut World Health Organization (WHO) (2), hampir enam juta kematian per tahun diakibatkan oleh asap rokok. Angka ini diperkirakan akan meningkat menjadi lebih dari 8 juta kematian pada tahun 2030. Asap rokok mengandung sekitar 4\% karbon monoksida (CO) yang cukup untuk meningkatkan kadar karboksi-hemoglobin (HbCO) darah seorang perokok sampai $10 \%$. Persentase ini cukup untuk mengganggu aktivitas dan kinerja mental (3). Karakteristik biologis

Korespondensi: Yuyun Erlina Susanti, Fakultas Kesehatan Masyarakat Universitas Airlangga, Jl. Mulyosari, Surabaya, Jawa Timur, Indonesia, e-mail: yuyun.erlinayes@gmail.com 
yang paling penting dari $\mathrm{CO}$ adalah kemampuannya untuk berikatan dengan hemoglobin $(\mathrm{Hb})$. Sifat ini menghasilkan pembentukan $\mathrm{HbCO}$ yang 200 kali lebih stabil dibandingkan oksi-hemoglobin $\left(\mathrm{HbO}_{2}\right)$. Keracunan CO menyebabkan penurunan kapasitas transportasi oksigen dalam darah oleh $\mathrm{Hb}$ dan penggunaan oksigen di tingkat seluler (4).

World Health Organization menyatakan bahwa asap rokok mengandung bahan toksik dan karsinogenik sehingga efek pada perokok pasif hampir sama dengan efek pada perokok aktif. Absorpsi asap rokok oleh perokok pasif dipengaruhi oleh jumlah produksi asap, dalamnya hisapan, ventilasi untuk penyebaran atau pergerakan asap, jarak dengan perokok, dan lamanya pajanan. Asap rokok juga mengandung CO sehingga para perokok dapat memajan dirinya sendiri dan asap rokok yang sedang dihisapnya (5). Asap rokok mampu memulai atau mempromosikan kerusakan oksidatif(6). Pemberian antioksidan merupakan terapi efektif yang dibutuhkan untuk mengontrol dan mengurangi stres oksidatif dalam tubuh (7). Stres oksidatif dapat dikendalikan oleh asupan antioksidan dari makanan yang selanjutnya akan memacu kerja antioksidan dalam tubuh (8). Melon (Cucumis melo) mempunyai kandungan karotenoid melon yang tinggi yaitu 640 SI/100 BDD (9). Karotenoid berfungsi sebagai antioksidan yang menangkap radikal bebas dan membantu mencegah kerusakan jaringan (10). Ekstrak melon telah dikembangkan sebagai suplemen makanan yang memiliki kandungan superoksida dismutase (SOD) tinggi yaitu $100 \mathrm{U} / \mathrm{mg}$ yang dikombinasikan dengan gliadin untuk melindungi degradasi asam lambung dan membantu penyerapan di usus sehingga dapat dilepas secara bertahap ke dalam sirkulasi sistemik (11).

Hal ini membuktikan perlu adanya penelitian untuk mengetahui sejauh mana manfaat ekstrak melon (Cucumis melo) untuk mencegah terhimpunnya senyawa oksidan secara berlebihan dalam tubuh akibat paparan asap rokok dengan cara melihat konsentrasi terhadap kadar $\mathrm{HbCO}$ pada hewan coba.

\section{BAHAN DAN METODE}

Penelitian yang dilakukan adalah eksperimen laboratoris dengan menggunakan control group post test design yaitu rancangan yang digunakan untuk mengukur pengaruh pemberian ekstrak melon (Cucumis melo) pada kelompok eksperimen dengan cara membandingkan perlakuan dengan kelompok kontrol terhadap kadar $\mathrm{HbCO}$. Sementara untuk pengelompokan dan pemberian perlakuan menggunakan metode rancangan acak lengkap (RAL). Penelitian dilaksanakan pada bulan April sampai Mei 2016. Penelitian membutuhkan waktu selama lima minggu dan dibagi dalam dua bagian yaitu minggu adaptasi selama 7 hari dan minggu perlakuan selama 28 hari. Penelitian dilakukan di Laboratorium Fakultas Kedokteran Universitas Airlangga Surabaya.

Sampel penelitian ini adalah tikus putih jantan (Rattus novergicus strain Wistar) usia 3-4 bulan. Besar sampel ditentukan dengan menggunakan rumus Federer yaitu sebanyak 25 ekor tikus putih jantan (Rattus novergicus strain Wistar). Kriteria inklusi penelitian ini adalah tikus putih jenis Rattus novergicus strain Wistar, jenis kelamin jantan, umur 3-4 bulan, berat badan $150-250 \mathrm{~g}$, warna bulu putih, dan tikus aktif. Kriteria eksklusinya adalah tikus yang selama penelitian tidak mau makan dan tikus yang kondisinya menurun atau mati

Tabel 1. Perlakuan untuk masing-masing kelompok

\begin{tabular}{cl}
\hline Kelompok & \multicolumn{1}{c}{ Perlakuan } \\
\hline & $\begin{array}{l}\text { Kelompok kontrol yang hanya diberikan pakan } \\
\text { tikus standar dengan kadar protein 17\% tanpa } \\
\text { adanya perlakuan berupa paparan asap rokok } \\
\text { dan pemberian ekstrak melon (Cucumis melo) } \\
\text { per oral. } \\
\text { Kelompok perlakuan yang diberikan pakan } \\
\text { II } \quad \begin{array}{l}\text { tikus standar dengan kadar protein 17\% dan } \\
\text { perlakuan berupa paparan asap rokok tetapi }\end{array} \\
\text { tanpa pemberian ekstrak melon (Cucumis melo) } \\
\text { per oral. } \\
\text { Kelompok perlakuan yang diberikan pakan tikus } \\
\text { standar dengan kadar protein 17\%, perlakuan } \\
\text { berupa paparan asap rokok dan pemberian } \\
\text { ekstrak melon (Cucumis melo) per oral dengan } \\
\text { dosis 3 IU/hari/ekor. } \\
\text { Kelompok perlakuan yang diberikan pakan tikus } \\
\text { standar dengan kadar protein 17\%, perlakuan } \\
\text { berupa paparan asap rokok dan pemberian } \\
\text { ekstrak melon (Cucumis melo) per oral dengan } \\
\text { dosis 4,5 IU/hari/ekor }\end{array}$ \\
Kelompok perlakuan yang diberikan makanan, \\
perlakuan berupa paparan asap rokok dan \\
pemberian ekstrak melon (Cucumis melo) per \\
oral dengan dosis 9 IU/hari/ekor.
\end{tabular}


selama penelitian berlangsung. Sampel penelitian dibagi menjadi 5 kelompok perlakuan (Tabel 1). Pemeliharaan dan perlakuan serta pengambilan hasil kadar $\mathrm{HbCO}$ dilakukan di Laboratorium Fakultas Kedokteran Universitas Airlangga Surabaya.

Variabel yang diteliti adalah kadar $\mathrm{HbCO}$ dalam darah tikus putih jantan galur Wistar dengan umur 3-4 bulan. Pada kelompok dengan perlakuan pemberian ekstrak melon diberikan ekstrak melon (SOD ekstrak melon + white protein matrix) 1 kali/hari sesuai dosis perhitungan dan paparan asap rokok dari rokok kretek tanpa filter dengan kandungan tar $38 \mathrm{mg}$ dan nikotin 2,2 mg yang diberikan $1 \mathrm{kali} / \mathrm{hari}$. Penelitian dilakukan selama 28 hari. Pada kelompok kontrol (I) tidak diberikan paparan asap rokok. Kelompok II - V dipapar asap rokok 1 batang sebanyak 1 kali/hari. Kelompok III - V memperoleh perlakuan tambahan yaitu pemberian ekstrak melon (Cucumis melo) dengan dosis yang berbeda dengan menggunakan tabel konversi perhitungan dosis.

Pada hari ke-28 perlakuan, tikus diinjeksi anestesi. Tikus diinjeksi menggunakan ketalar secara intra muskuler pada paha tikus. Saat tikus dalam kondisi teranestesi, dilakukan pembedahan untuk mengambil darah dari jantung. Sampel darah disentrifus selama 15 menit dengan kecepatan $3000 \mathrm{rpm}$, diambil serum darah untuk pemeriksaan kadar $\mathrm{HbCO}$. Alat yang digunakan dalam penelitian ini adalah kandang tikus beserta kelengkapan tempat makanan dan minuman, timbangan elektrik, sarung tangan, smoking pump, termometer, tabung mikrohematokrit, tabung ependorf, timbangan analitik, sonde lambung, homogenizer, mikro pipet dan tip, water bath, vortex, tabung polypropylene, ice bath, sentrifuge, cartrideges $\mathrm{C} 18$, dan spektrofotometer untuk pemeriksaan kadar $\mathrm{HbCO}$.

Data kadar HbCO yang terkumpul dianalisis dengan menggunakan uji Anova One Way untuk melihat apakah terdapat perbedaan yang nyata atau sangat nyata antar perlakuan yang dilanjutkan dengan uji least significance difference (LSD) untuk melihat seberapa besar perbedaan setiap kelompok perlakuan dengan tingkat kemaknaan 95\% $(\mathrm{p}<0,05)$. Penelitian ini telah lolos kaji etik oleh Komisi Etik Penelitian Kesehatan Fakultas Kesehatan Masyarakat Universitas Airlangga dengan nomor: 210 - KEPK.

\section{HASIL}

Pada Tabel 2 dan Gambar 1 dapat dilihat rerata kadar HbCO paling tinggi terdapat pada kelompok kontrol positif yaitu yang diberikan pakan standar dan perlakuan berupa paparan asap rokok tetapi tanpa pemberian ekstrak melon yaitu sebesar $9,77 \pm 0,81 \%$.

Tabel 2. Nilai rerata dan standar deviasi variabel kadar HbCO pada kelompok kontrol dan perlakuan

\begin{tabular}{lccc}
\hline \multirow{2}{*}{\multicolumn{1}{c}{ Kelompok }} & \multicolumn{3}{c}{ Kadar HbCO (\%) } \\
\cline { 2 - 4 } & Mean \pm SD & Min & Maks \\
\hline Kontrol negatif (I) & $4,59 \pm 0,78$ & 3,29 & 5,37 \\
Kontrol positif (II) & $9,77 \pm 0,81$ & 8,92 & 10,84 \\
Ekstrak 3 IU/hari (III) & $9,42 \pm 0,99$ & 8,19 & 10,64 \\
Ekstrak 4,5 IU/hari (IV) & $8,02 \pm 0,74$ & 6,93 & 8,82 \\
Ekstrak 9 IU/hari (V) & $7,35 \pm 0,75$ & 6,55 & 8,33 \\
\hline
\end{tabular}

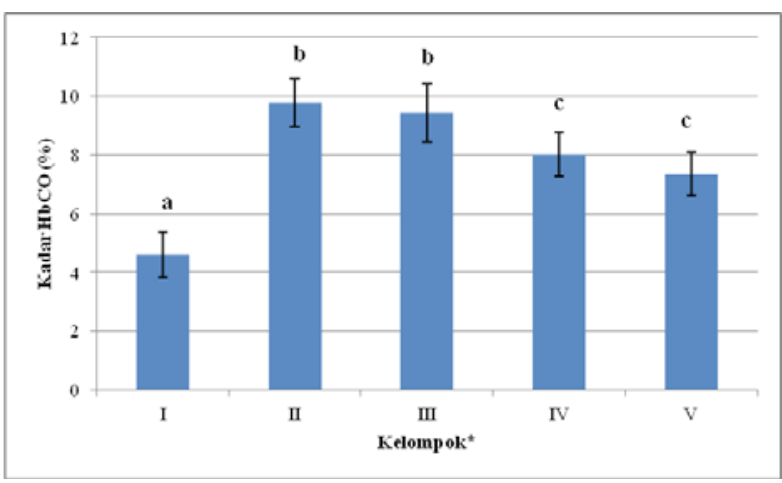

Gambar 1. Rerata kadar HbCO pada tikus Wistar jantan

*Kelompok: I= kelompok kontrol negatif; II = kelompok kontrol positif; III = kelompok ekstrak melon $3 \mathrm{IU} / \mathrm{hr}$; IV = kelompok ekstrak melon 4,5 IU/hr; V = kelompok ekstrak melon $9 \mathrm{IU} / \mathrm{hr}$;

$\mathrm{a}, \mathrm{b}, \mathrm{c}=$ huruf yang berbeda menunjukkan perbedaan yang bermakna berdasarkan uji LSD pada $\alpha=0,05$

Perbedaan rerata kadar $\mathrm{HbCO}$ pada kelompok kontrol maupun kelompok perlakuan diketahui dengan uji One-way ANOVA. Syarat dilakukan uji ANOVA adalah data berskala interval dan rasio, berdistribusi normal, dan varian data homogen. Sementara untuk mengetahui apakah data berdistribusi normal atau tidak maka digunakan uji statistik one sample KolmogorovSmirnov.

Dari Tabel 3 didapatkan data berdistribusi normal ( $p>0,05$ ). Data pengukuran kadar HbCO berdistribusi normal maka dilanjutkan dengan melakukan uji homogenitas varian (Levene Test). Pada uji Anova 
Tabel 3. Uji normalitas data kadar HbCO pada kelompok kontrol dan perlakuan

\begin{tabular}{lc}
\hline \multicolumn{1}{c}{ Kelompok } & p \\
\hline Kontrol negatif (I) & 0,784 \\
Kontrol positif(II) & 0,994 \\
Ekstrak 3 IU/hari (III) & 0,999 \\
Ekstrak 4,5 IU/hari (IV) & 0,965 \\
Ekstrak 9 IU/hari (V) & 0,968 \\
\hline
\end{tabular}

diasumsikan, varian dari variabel yang ada adalah homogen. Oleh karena itu, perlu dilihat dari homogenitas dari varian variabel yang ada dengan Levene Test yang bertujuan untuk mengetahui semua kelompok data mempunyai varian yang homogen $(p>0,05)$ atau tidak $(\mathrm{p}<0,05)$.

Dari hasil Levene Test nilai signifikansi (p) kadar $\mathrm{HbCO}$ sebesar 0,879 . Hal ini berarti variabel tersebut memiliki varian yang sama sehingga dapat dianalisis dengan uji Anova. Nilai signifikansi kadar $\mathrm{HbCO}$ lebih besar dibandingkan dengan nilai $\alpha=0,05$ yang berarti varian variabel dapat dikatakan homogen. Perbedaan kadar $\mathrm{HbCO}$ antara kelompok kontrol dan kelompok perlakuan dilakukan uji Anova dengan tingkat kepercayaan $95 \%$ diperoleh $\mathrm{p}$ $=0,000$. Artinya, minimal ada sepasang kelompok yang memiliki perbedaan rerata kadar $\mathrm{HbCO}$. Lebih lanjut, untuk mengetahui pasangan kelompok mana yang berbeda maka uji Anova One Way dilanjutkan dengan uji Post Hoc dengan menggunakan LSD.

Hasil LSD menunjukkan adanya perbedaan rerata kadar $\mathrm{HbCO}$ pada masing-masing kelompok yaitu variabel kadar $\mathrm{HbCO}$ pada kelompok kontrol negatif menunjukkan ada perbedaan nyata antarkelompok kontrol negatif dengan kelompok kontrol positif, kelompok pemberian ekstrak melon (3 IU/hr), pemberian ekstrak melon (4,5 IU/hr), dan pemberian ekstrak melon ( $9 \mathrm{IU} / \mathrm{hr})$, setiap kelompok ini memiliki nilai signifikansi $\mathrm{p}=0,000$. Variabel kadar HbCO pada kelompok kontrol positif menunjukkan ada perbedaan nyata antarkelompok kontrol positif dengan kelompok kontrol negatif, kelompok pemberian ekstrak melon (4,5 IU/hr), dan pemberian ekstrak melon (9 IU/hr) dengan nilai signifikansi setiap kelompok adalah $\mathrm{p}=0,000 ; \mathrm{p}=0,003$; dan $\mathrm{p}=0,000$. Sementara itu, pada kelompok kontrol positif dengan pemberian ekstrak melon (3 IU/hr) tidak ada perbedaan nyata $(\mathrm{p}=0,505)$.
Lebih lanjut, variabel kadar HbCO pada kelompok pemberian ekstrak melon ( $3 \mathrm{IU} / \mathrm{hr}$ ) menunjukkan adanya perbedaan nyata antarkelompok pemberian ekstrak melon ( $3 \mathrm{IU} / \mathrm{hr})$ dengan kelompok kontrol negatif $(\mathrm{p}=0,000)$; kelompok pemberian ekstrak melon $(4,5 \mathrm{IU} / \mathrm{hr})(\mathrm{p}=0,01)$; dan kelompok pemberian ekstrak melon ( $9 \mathrm{IU} / \mathrm{hr}$ ) $(\mathrm{p}=0,001)$ sedangkan pada kelompok pemberian ekstrak melon (3 IU/hr) dengan kelompok kontrol positif tidak terdapat perbedaan nyata $(\mathrm{p}=0,505)$. Variabel kadar $\mathrm{HbCO}$ pada kelompok pemberian ekstrak melon $(4,5 \mathrm{IU} / \mathrm{hr})$ juga menunjukkan ada perbedaan nyata antarkelompok pemberian ekstrak melon (4,5 IU/hr) dengan kelompok kontrol negatif $(\mathrm{p}=0,000)$; kelompok kontrol positif $(\mathrm{p}=0,003)$; dan kelompok pemberian ekstrak melon (3 $\mathrm{IU} / \mathrm{hr})(\mathrm{p}=0,014)$ sedangkan pada kelompok pemberian ekstrak melon (4,5 IU/hr) dengan kelompok pemberian ekstrak melon (9 IU/hr) tidak terdapat perbedaan nyata $(\mathrm{p}=0,214)$. Demikian juga dengan variabel kadar $\mathrm{HbCO}$ pada kelompok pemberian ekstrak melon (9 IU/hr) yang menunjukkan ada perbedaan nyata antar kelompok pemberian ekstrak melon (9 IU/hr) dengan kelompok kontrol negatif $(\mathrm{p}=0,000)$; kelompok kontrol positif $(\mathrm{p}=0,000)$; dan kelompok pemberian ekstrak melon (3 $\mathrm{IU} / \mathrm{hr})(\mathrm{p}=0,001)$ sedangkan pada kelompok pemberian ekstrak melon (9 IU/hr) dengan kelompok pemberian ekstrak melon (4,5 IU/hr) tidak terdapat perbedaan nyata $(p=0,214)$.

\section{BAHASAN}

Penelitian ini bertujuan untuk melihat apakah ada pengaruh pemberian ekstrak melon (Cucumis melo) terhadap kadar $\mathrm{HbCO}$. Hasil yang diperoleh dari penelitian ini secara preventif menunjukkan bahwa kelompok yang diberi paparan asap rokok disertai dengan pemberian ekstrak melon menunjukkan adanya penurunan kadar $\mathrm{HbCO}$ dibandingkan dengan kelompok yang hanya dipapar asap rokok tanpa diberi ekstrak melon. Rerata kadar $\mathrm{HbCO}$ yang hanya dipapar asap rokok sebesar $9,77 \pm 0,81 \%$ sedangkan rata-rata kadar $\mathrm{HbCO}$ terendah ditemukan pada kelompok perlakuan yang mendapat ekstrak melon (9 IU/hr) dengan rerata $7,55 \pm 0,97 \%$. Hal ini didukung penelitian sebelumnya yang menyatakan bahwa kelompok yang dipapar asap 
rokok 3 kali sehari menunjukkan rerata $\mathrm{HbCO}$ sebesar $13,2 \pm 1,3 \%$ (12).

Rokok mengandung hampir 4000 senyawa kimia yang 60 zat diantaranya bersifat karsinogenik dan adiktif. Asap rokok adalah biphasic (gas dan partikulat). Dalam fase gas, $\mathrm{CO}$ dilepaskan dan menjadi penyebab stres oksidatif sedangkan dalam fase partikulat, nikotin dan tar yang dilepaskan. Asap rokok mengandung beberapa bahan kimia beracun, zat mutageni, dan karsinogen termasuk nikotin dan metaboliknya, kotinine, polonium radioaktif, benzopyrene, dimethylbenzanthrancene, naftalen, methylnaphtalene, hidrokarbon aromatik polisiklik (PAHs), dan cadmium (13).

Asap rokok mengandung banyak senyawa yaitu oksidan dan prooksidan yang mampu menghasilkan radikal bebas dan meningkatkan stres oksidatif di vivo (14). Rokok adalah salah satu sumber reactive oxygen species (ROS). Reaktivitas ROS akan merusak DNA, protein, dan lipid penyusun sel. Tingginya kadar ROS dalam tubuh tergambarkan pada rendahnya aktivitas enzim SOD, katalase, dan glutation peroksidase, serta kadar vitamin C, E, dan $\beta$-karoten. Kondisi seperti ini akan menyebabkan stres oksidatif (8). Berdasarkan penelitian sebelumnya menunjukkan bahwa merokok dapat meningkatkan peroksidasi lipid, dapat menginduksi aktivitas enzim antioksidan sebagai mekanisme mempertahankan diri dan menghasilkan gangguan keseimbangan yang dinamis antara oksidasi dan antioksidan (14).

Keadaan sel atau jaringan kekurangan oksigen disebut dengan hipoksia yang dapat disebabkan oleh berkurangnya suplai oksigen akibat transportasi oksigen oleh hemoglobin $\mathrm{Hb}$ terganggu. Kondisi $\mathrm{Hb}$ tersebut tidak dapat berfungsi normal akibat terikat dengan CO. Hipoksia ensefalopati yang terjadi akibat dari keracunan $\mathrm{CO}$ adalah karena injuri reperfusi yaitu peroksidasi lipid dan pembentukan radikal bebas yang menyebabkan mortalitas dan morbiditas. Studi telah menunjukkan adanya pelepasan radikal bebas oksida nitrat dari platelet dan endothelium pembuluh darah pada pajanan CO dengan konsentrasi 100 ppm. Adanya HbCO tidak hanya mengurangi jumlah oksigen dalam darah, tetapi pelepasan oksigen ke jaringan menjadi lebih sedikit (15). Hal ini dapat dilihat pada tingginya kadar $\mathrm{HbCO}$ pada kelompok dengan paparan asap rokok yang tidak diberikan ekstrak melon.
Perlakuan pada hewan coba secara preventif dengan menggunakan ekstrak melon dapat mencegah kenaikan kadar $\mathrm{HbCO}$ yang diakibatkan oleh paparan asap rokok. Peranan HbCO adalah sebagai biomarker potensial untuk pajanan $\mathrm{CO}$ dalam memperkirakan hubungan antara pajanan dan tingkat $\mathrm{HbCO}$ dalam darah. Inhalasi karbonmonoksida berlangsung cepat dan diserap ke dalam darah dan didistribusikan ke seluruh tubuh. Distribusi CO dalam tubuh mencerminkan ikatan CO terhadap protein heme. Studi pada hewan mengevaluasi pajanan $\mathrm{CO}$ yang menghasilkan konsentrasi $\mathrm{HbCO}$ jauh lebih tinggi ( $\mathrm{HbCO}>50 \%$ ) dibandingkan dengan studi klinis terkontrol pada manusia (16).

Melon (Cucumis melo) mempunyai kandungan karotenoid melon yang tinggi yaitu 640 SI/100 BDD. Ekstrak melon (Cucumis melo) telah dikembangkan sebagai suplemen makanan yang memiliki kandungan SOD tinggi yaitu $100 \mathrm{U} / \mathrm{mg}$ yang dikombinasikan dengan gliadin untuk melindungi degradasi asam lambung dan membantu penyerapan di usus sehingga dapat dilepas secara bertahap ke dalam sirkulasi sistemik (11). Gliadin gandum biopolymeric sebagai molekul aktif yang digunakan untuk melindungi proses pencernaan $(17,18)$ yang berinteraksi dengan penyerapan pada epitel usus sehingga dapat melakukan pengiriman mukosa dari molekul aktif $(19,20)$. Interaksi hidrofobik antara gliadin dan protein bisa mendefinisikan efektivitas secara oral dari SOD sehingga dihasilkan gliadin kombinasi monophasic atau protein yang mampu menargetkan permukaan biologis enterosit dan dapat meningkatkan penyerapan protein (21). Pada manusi, ekstrak melon yang disarankan sesuai dosis yaitu mengandung SOD sebesar $250 \mathrm{IU} /$ hari setara dengan 540 g Cucumis melo variance Cantalupensi.

Kesimpulan dari penelitian ini adalah bahwa paparan asap rokok dapat meningkatkan kadar $\mathrm{HbCO}$ dalam tubuh. Penggunaan ekstrak melon dapat memberikan pengaruh pada penurunan kadar $\mathrm{HbCO}$ yang diakibatkan adanya paparan asap rokok yaitu sebesar $18 \%$. Penggunaan dosis yang sesuai yaitu sebesar $250 \mathrm{IU} /$ hari ekstrak melon (Cucumis melo) + gliadin setara dengan 540 g melon (Cucumis melo variance Cantalupensi) dapat memberikan pengaruh yang signifikan. Pemberian ekstrak melon sesuai dosis (250 
IU/hari) dapat menghambat pembentukan $\mathrm{HbCO}$ tetapi masih belum dapat meniadakan terbentuknya $\mathrm{HbCO}$ dalam waktu 28 hari.

\section{SIMPULAN DAN SARAN}

Pemberian ekstrak melon selama 28 hari secara signifikan dapat menurunkan kadar $\mathrm{HbCO}$ pada tikus Wistar jantan yang diberi paparan asap rokok. Namun, perlu dilakukan penelitian lebih lanjut dengan lama penelitian yang lebih panjang untuk mengetahui efektivitas ekstrak melon dalam meniadakan kadar $\mathrm{HbCO}$ pada paparan asap rokok. Ekstrak melon (Cucumis melo) dapat diberikan pada perokok aktif maupun pasif dengan dosis 1 x $250 \mathrm{IU}$ atau setara $540 \mathrm{~g}$ melon sebagai antioksidan yang berperan dalam penurunan radikal bebas dalam darah.

\section{Pernyataan konflik kepentingan}

Penulis menyatakan tidak ada konflik kepentingan dengan pihak-pihak yang terkait dalam penelitian ini

\section{RUJUKAN}

1. Trixie S, Amalia R. Perilaku merokok di kalangan mahasiswa Universitas Muhammadiyah Semarang. Prosiding Seminar Nasional Unimus 2010. Jurnal Unimus 2010;2(1):172-80.

2. WHO. Global youth tobacco survey. [series online] 2014 [cited 2016 Jan 1]. Available from: URL: http://www.who. int/tobacco/surveillance/survey/gyts/country_reports.

3. West, John B. Patofisiologi paru esensial, edisi 6. Jakarta: EGC; 2010.

4. Amin M. Pemeriksaan dan interpretasi faal paru. PKB Pulmonologi dan Ilmu Kedokteran Respirasi Surabaya. Surabaya: FK Unair; 2013.

5. WHO. Global adult tobacco survey. [series online] 2011 [cited 2016 Jan 1]. Available from: URL: http://www.who. int/tobacco/surveillance/survey/gats/en/.

6. Luchese C, Simone P, Nogueira CW. Brain and lungs of rats differently affected by cigarette smoke exposure: antioxidant effect of an organoselenium compound. Pharmacol Res 2009;59(3):194-201.

7. Wolfgang D, Karl O, Wilfried R. Oxidative stress and free radicals in COPD - implications andrelevance for treatment. Int Journal Chron Obstruct Pulmon Dis 2014;9:1207-24.
8. Winarsi H. Antioksidan alami dan radikal bebas. Potensi dan aplikasinya dalam kesehatan. Yogyakarta: Penerbit Kanisius; 2007.

9. Wirakusumah ES. Buah dan sayur untuk terapi. Jakarta: Penebar Swadaya; 2006.

10. Olivia F, Alam S, Hadibroto I. Seluk beluk food suplement. Jakarta: PT Gramedia Pustaka Utama; 2014.

11. Romao S. Theraupetic value of oral suplementation with melon superoxide dismutase and wheat gliadin combination. Nutrition 2015;31(3):430-6.

12. Frank SB, Samuel SV, Karla MPP, Lanzetti M, Pimenta WA, Zin WA, et al. Long-term exposure to cigarette smoke impairs lung function and increase HMGB-1 expression in mice. Respir Physiol Neurobiol 2011;177(2):120-6.

13. Harlev A, Ashok A, Sezgin OG, Amit S, Stefan SP. Smoking and male infertility: an evidence-based review. World J Mens Health 2015:33(3): 143-60.

14. Kocyigit A, Erel O, Gur S. Effects of tobacco smoking on plasma selenium, zinc, copper and iron concentrations andrelated antioxidative enzyme activities. Clin Biochem 2001;34(8):629-33.

15. Soemirat JD, Roosmini, Indah RS, Khatarina O. Toksikologi lingkungan. Yogyakarta: Gajah Mada University Press; 2009.

16. ATSDR. Toxicological profile for carbon monoxide poisoning. [series online] 2016 [cited 2016 Mar 1]. Available from: URL: https://www.atsdr.cdc.gov/ ToxProfiles/index.asp.

17. Renard D, Robert P, Lavenant L, Melcion D, Popineau Y, Schmitt C, et al. Biopolymericcolloidal carriers for encapsulation or controlled release applications. Int $\mathrm{J}$ Pharm 2002;242(1-2):163-6.

18. Mauguet MC, Legrand J, Brujes L, Carnelle G, Larre C, Popineau Y. Gliadin matrix for microencapsulation processes by simplecoacervation method. J Microencapsul 2002;19(3):377-84.

19. Ezpeleta I, Arangoa MA, Irache JM, Stainmesse S, Chabenet C, Orecchioni AM. Preparation of ulex europaeuslectin-gliadin nanoparticle conjugates and their interaction with gastrointestinalmucus. Int J Pharm 1999;191(1):25-32.

20. Fassano A, Not T, Wang W, Uzzau S, Berti I, Goldblum SE. Zonulin, a newly discovered modulator of in-testinal permeability, and its expression in celiac disease. Lancet 2000;355(9214):1518-9.

21. Calderon DB, Yepiz-Plascencia, Bøg-Hanse N. Hydrophobic interactions between gliadin and proteins and celiac disease. Life Sci 1996;59(23):1951-60. 